\title{
A tradição da Odontologia no neolítico se constitui na mais antiga evidência de nossa profissão
}

\begin{abstract}
Avanços têm levado a menores índices CPOD na maior parte da população mundial que tem acesso ao tratamento dentário. Entretanto, a Odontologia ainda é associada ao tratamento da cárie, não apenas porque essa condição começou a ser vencida de forma relativamente recente, mas também porque esse é o tipo de intervenção mais ancestral que se provê à boca. Achados recentes deslocaram ainda mais para o passado os primeiros vestígios do tratamento dentário.

Um estudo publicado no mês de abril deste ano, na revista Nature ${ }^{1}$, descreve os achados de um sítio neolítico no Paquistão. Nove crânios pertencentes a quatro mulheres, dois homens e três indivíduos de gênero não identificado exibiam dentes com preparos cavitários delicados feitos, em quase todos os casos, na superfície oclusal dos dentes. Eles viveram em um período que se iniciou há 9.000 anos e se encerrou há 7.500.

Os preparos feitos em $1^{\text {os }}$ e $2^{\text {os }}$ molares inferiores e
\end{abstract}

superiores possuíam de 1,3 a 3,2 $\mathrm{mm}$ de diâmetro e profundidades que variavam entre 0,5 e $3,5 \mathrm{~mm}$. Microscopia eletrônica de varredura, microtomografia e microscopia de luz mostraram que esses dentes foram perfurados com uma broca e, em pelo menos um indivíduo, submetidos a preparo manual com delicados instrumentos. A presença de cárie associada a alguns preparos mostra que a intervenção provavelmente fora terapêutica. Como algumas perfurações expuseram dentina, é possivel que algum tipo de preenchimento tenha sido feito, mas nenhuma evidência permaneceu que pudesse confirmar essa hipótese.

Presumivelmente, a tecnologia utilizada fora desenvolvida para a produção de contas de colares e outros ornamentos e, subseqüentemente, transferida para uma forma de Odontologia ancestral. É interessante notar que a prática se estendeu por um período de 1.500 anos, mas cessou há cerca de 6.500 anos, apesar da baixa saúde dentária que ainda persistiu.

\section{Próteses totais suportadas por implantes impactam positivamente nas atividades sociais e sexuais quando comparadas com próteses totais convencionais}

Dentes possuem uma grande importância no relacionamento de seres humanos. Eles estão presentes na demonstração de diferentes sentimentos e também contribuem para o julgamento de diferentes atributos de personalidade e comportamento. Dessa forma, o desempenho de próteses poderia, teoricamente, influenciar nas atividades do dia-a-dia, inclusive nas sexuais. Um estudo publicado recentemente no Journal of Dentistry ${ }^{2}$ analisou o impacto de próteses totais mandibulares convencionais e suportadas por dois implantes, exatamente sobre essas questões.

Um total de 102 indivíduos foi incluído em um estudo clínico controlado randomizado, no qual dois grupos foram formados. O primeiro recebeu próteses totais convencionais $(\mathrm{n}=48)$ e o segundo próteses totais sobre implantes (PTImp; n=54). Questionários foram utilizados para identificar a influência ou comportamento dessas próteses nas atividades sexuais e sociais. Foram incluídos itens como a recusa de conversas e convites, o sentimento de desconforto ao beijar e ao se relacionar sexualmente e

* Doutor em Biologia - Morfologia, Laboratório de Microscopia Eletrônica da Universidade de Brasília. Mestre em Ortodontia pela Universidade Federal do Rio de Janeiro. Clínica privada focada no atendimento de pacientes adultos. a frouxidão das próteses durante essas atividades. Escalas categóricas foram utilizadas para obter escores na época de instalação das próteses e após dois meses de uso. A saúde oral relacionada à qualidade de vida foi medida com o questionário Perfil de Impacto da Saúde Oral (PISO).

Dois meses após a instalação das próteses, os indivíduos do grupo PTImp exibiram escores significativamente diferentes - e melhores - na frouxidão das próteses ao comer, falar, bocejar e beijar, bem como no PISO. Os indivíduos com próteses ancoradas em implantes também se sentiram menos desconfortáveis não somente para beijar, mas também durante as relações sexuais.

Os achados dessa pesquisa salientam o ganho que indivíduos podem ter ao receber próteses sobre implantes, quando comparados àqueles que utilizam as convencionais. Os ganhos não estão presentes apenas nas funções mastigatórias. Eles podem ser percebidos em outros contextos, tal como no relacionamento sexual.

1. COPPA, A. et al. Early neolithic tradition of dentistry. Nature, London, v. 440, p. 755-756, apr. 2006.

2. HEYDECKE, G. et al. The impact of conventional and implant supported prostheses on social and sexual activities in edentulous adults: results from a randomized trial 2 months after treatment. J Dent, Oxford, v. 33, no. 8, p. 649-657, 2005. 